\title{
Studi Kelayakan Coffee Class Pada Mase Coffee Lab di Bantul, Yogyakarta
}

\author{
Adita Utami*¹, Fatma Dewi Sinurat $^{2}$, Fransisko ${ }^{3}$ \\ ${ }^{1,2,3}$ Program Studi Teknik Sipil, Universitas Pertamina, Jl. Teuku Nyak Arief, \\ Simprug, Jakarta Selatan, 12220 \\ E-mail: adita.utami@universitaspertamina.ac.id
}

Received 22 September 2020; Reviewed 30 September 2020; Accepted 04 December 2020 Journal Homepage: http://jurnal.borneo.ac.id/index.php/borneoengineering

\begin{abstract}
Coffee Class on Mase Coffee Lab is a business which provides knowledges about coffee industry. The business was founded with basis that there is a growth in interest of coffee and only few similar businesses already exist. With that uniqueness, a research of feasibility study is needed. The aim is to determine the feasibility of the investment that is already ongoing. The data is obtained from either owner and literature study. Then using the data, feasibility study is conducted by analyzing non-financial aspect, financial aspect, continued with further evaluation by doing sensitivity analysis. Non-financial aspect consists of market aspect, technical aspect, management and law aspect also social, economic and environmental aspect. Financial aspect consists of evaluation of Net Present Value (NPV), Payment Back Period (PBP), Benefit to Cost Ratio (BCR) and Internal Rate of Return (IRR). The result obtained are, consecutively, IDR 49,046,768.59, 2 years, 1,21, and 57,84\%. Then sensitivity analysis is done for participant numbers, and operational cost. From analysis, it can be concluded that the investment on the business is feasible and it is sensitive to the number of participants.
\end{abstract}

Keywords: Feasibility Study, NPV, BCR, IRR, Sensitivity

\begin{abstract}
Abstrak
Kelas kopi pada Mase Coffee Lab merupakan sebuah usaha yang memberikan berbagai pengetahuan tentang industri kopi. Usaha didirikan dengan dasar adanya kenaikan peminatan terhadap kopi dan masih sedikit adanya usaha sejenis. Karena keunikan usaha tersebut, perlu dilakukan sebuah penelitian berupa studi kelayakan. Tujuannya adalah untuk mengetahui kelayakan dari investasi yang sedang berlangsung. Data yang digunakan bersumber dari pemilik dan studi literatur. Dari data tersebut dilakukan analisis terhadap aspek non finansial, aspek finansial kemudian dilanjutkan dengan analisis sensitivitas. Aspek non finansial terdiri dari aspek pasar, aspek teknis, aspek manajemen dan hukum serta aspek sosial, ekonomi dan lingkungan. Aspek finansial terdiri dari perhitungan Net Present Value (NPV), Payment Back Period (PBP), Benefit to Cost Ratio (BCR) dan Internal Rate of Rerturn (IRR). Didapatkan hasil yaitu, secara urut bernilai $R p$ 49,046,768.59, 2 tahun, 1,21, dan 57,84\%. Kemudian dilakukan analisis sensitivitas untuk jumlah peserta dan biaya operasional. Dari hasil analisis, dapat disimpulkan bahwa investasi yang dilakukan layak dan usaha sensitif terhadap jumlah peserta.
\end{abstract}

Kata kunci: Studi Kelayakan, NPV, BCR, IRR, Sensitivitas 


\section{Pendahuluan}

Indonesia memiliki peran yang penting dalam industri kopi dunia. Hal tersebut dapat dilihat dari tingginya tingkat produksi dan konsumsi di dunia (International Coffee Organization, 2017). Di Indonesia sendiri, kopi merupakan salah satu komoditas perkebunan terpenting, dan diperkirakan terjadi peningkatan konsumsi sebesar 8,22\% untuk periode 2016-2021 (Kementrian Pertanian, 2018). Kedua hal tersebut merupakan sebuah potensi bagi para pelaku industri kopi. Kopi telah beralih peran dari sebatas hal yang biasa dinikmati sehari hari, menjadi hobi dan gaya hidup. Adanya peningkatan konsumsi tersebut menyebabkan maraknya kafe dan kedai kopi pada saat ini (Nurikhsan, 2019). Sebagaimana peningkatan yang terjadi di Yogyakarta. Berdasarkan Bernas.id tahun 2018 terdapat sebanyak 1100 kedai kopi, mengingkat dari jumlahnya di tahun 2014 dan 2015 masing masing 350 kedai dan 600 kedai. Agar tetap dapat berkompetisi dengan yang lain, sebuah kedai kopi harus memiliki kulatias yang tinggi.

Pengolahan kopi memerlukan proses yang panjang serta membutuhkan keahlian. Untuk itu dibutuhkan dasar pengetahuan yang kuat agar didapatkan kualitas kopi yang tinggi disetiap prosesnya (Sanaky , 2018). Namun belum banyak tersedia pengetahuan tentang kopi yang dapat di akses dengan mudah untuk umum. Dengan latar belakang tersebut, dibuka sebuah usaha kelas kopi sebagai bagian dari bisnis kedai kopi Mase Coffee Lab di Bantul, Yogyakarta. Kelas kopi Mase Coffe Lab memberikan pengetahuan tentang industri kopi seperti home brewing, farming, dan roasting. Selain untuk umum, kelas diperuntukkan untuk barista, roaster, maupun untuk bagi yang ingin memulai usaha di industri kopi. Keunikan usaha tersebut dalam bidang industri kopi menimbulkan pertanyaan bagi penulis tentang bagaimana kelakannya sebagai usaha.

Untuk itu, penelitian mengenai studi kelayakan kelas kopi pada Mase Coffee Lab dilakukan. Tujuannya adalah untuk mengetahui kelayakan sebuah investasi pada usaha tersebut dengan meninjau aspek non finansial dan aspek finansial serta sensitivitas dari faktor yang mempengaruhinya. Hasil penelitian ini diharapkan dapat bermanfaat pagi pelaku usaha serta investor dalam pengambilan keputusan di masa mendatang.

\section{Kajian Wilayah Studi}

Coffee Mase Lab merupakan bisnis kedai kopi yang dibentuk oleh dua orang mahasiswa Universitas Muhammadiyah Yogyakarta di tahun 2016. Salah satu produknya yaitu berupa kelas kopi, dibuka pada akhir Desmber 2018, dengan alasan utama yaitu masih besarnya peluang bisnis tersebut. Usaha dengan sumber dana pribadi ini dilakukan di sebuah bangunan sewa satu lantai dengan luas $60 \mathrm{~m}^{2}$. Bangunan terletak di sebelah timur Jl. Ring Road Selatan Nasional RT 3, dengan alamat Jl. Nulis Puluhan No. 122, Geblagan, Tamantirto, Kec. Kasihan, Bantul, Daerah Istimewa Yogyakarta. Gambar 1 menunjukkan lokasi usaha tampak atas, yang dibatasi oleh Illalang internet cafe dan bakery \& resto tepat di sebelah utara dan selatan lokasi.

Kelas kopi merupakan bagian dari usaha Mase Coffee Lab. Beroperasi pada bangunan yang sama, investasi kelas kopi tersebut dimulai pada akhir tahun 2018. Usaha kelas kopi tersebut telah berlangsung selama satu tahun dari tahun 2019 dan direncanakan memiliki masa investasi 5 tahun. Pada awal investasi tersebut telah diidentifikasi rincian finansial untuk investasi, pengeluaran, dan pemasukan.

\section{Rincian Biaya Investasi}


Investasi kelas kopi terdiri dari biaya pengadaan alat mengajar, biaya promosi kelas, serta biaya bangunan awal. Biaya tersebut terdiri dari biaya renovasi ruang, biaya sewa, air dan listrik untuk 2 bulan. Total biaya investasi yang diperlukan adalah sejumlah Rp 25.000.000,00 pada Tabel 1 .

Tabel 1. Rincian Biaya Investasi

\begin{tabular}{llr}
\hline \multicolumn{1}{c}{ Komponen } & \multicolumn{2}{c}{ Biaya } \\
\hline Pengadaan alat & $\mathrm{Rp}$ & $15.900 .000,00$ \\
Promosi & $\mathrm{Rp}$ & $1.610 .000,00$ \\
Renovasi ruang & $\mathrm{Rp}$ & $6.000 .000,00$ \\
Air & $\mathrm{Rp}$ & $90.000,00$ \\
Listrik & $\mathrm{Rp}$ & $400.000,00$ \\
Sewa bangunan & $\mathrm{Rp}$ & $1.000 .000,00$ \\
\hline \multicolumn{1}{c}{ Total } & $\mathrm{Rp}$ & $25.000 .000,00$ \\
\hline
\end{tabular}

\section{Identifikasi Pendapatan}

Sumber pendapatan yaitu pembayaran oleh peserta yang mengikuti kelas kopi. Pada tahun pertama terdapat 201 peserta yang mengikuti kelas, dengan total pendapatan yaitu sejumlah $\mathrm{Rp}$ 104.500.000,00. Untuk tahun-tahun berikutnya, diprediksi akan terjadi peningkatan peserta sebesar 8\% (Majalah Hortus, 2019). Sesuai peraturan, pendapatan tersebut harus dikurangkan dengan pajak. Nilai pajak untuk usaha ini adalah $0,05 \%$.

Tabel 2. Pendapatan Setelah Pajak untuk 5 Tahun

\begin{tabular}{ccc}
\hline Tahun & & Pemasukan \\
\hline 2019 & $\mathrm{Rp}$ & $103.978 .000,00$ \\
2020 & $\mathrm{Rp}$ & $112.296 .000,00$ \\
2021 & $\mathrm{Rp}$ & $121.280 .000,00$ \\
2022 & $\mathrm{Rp}$ & $130.982 .000,00$ \\
2023 & $\mathrm{Rp}$ & $141.462 .000,00$ \\
\hline
\end{tabular}

\section{Identifikasi Pengeluaran}

Biaya pengeluaran terdiri dari biaya variabel dan biaya tetap. Biaya variabel yaitu biaya bahan baku yang nilainya bergantung pada jumlah peserta (Nuryanti, 2017). Biaya tetap terdiri dari biaya air, listrik, perawatan, sewa bangunan dan gaji untuk dua pegawai. Terdapat peningkatan sebanyak $1 \%$ pertahun untuk gaji pegawai. Untuk biaya sewa, terdapat peningkatan sejumlah $\mathrm{Rp} 500.000,00$ per tahun. Alat yang dimiliki saat investasi diperkirakan tidak dapat berfungsi pada tahun ketiga, dan dilakukan pengadaan alat kembali.

Tabel 3. Rincian Pengeluaran Tahun ke-1

\begin{tabular}{llr}
\hline \multicolumn{1}{c}{ Komponen } & \multicolumn{1}{c}{ Biaya } \\
\hline Bahan baku & $\mathrm{Rp}$ & $22.035 .000,00$ \\
Air & $\mathrm{Rp}$ & $529.000,00$ \\
Listrik & $\mathrm{Rp}$ & $2.502 .000,00$ \\
Perawatan & $\mathrm{Rp}$ & $1.000 .000,00$ \\
Gaji pegawai & $\mathrm{Rp}$ & $60.000 .000,00$ \\
Sewa bangunan & $\mathrm{Rp}$ & $6.000 .000,00$ \\
\hline \multicolumn{1}{c}{ Total } & $\mathrm{Rp}$ & $92.066 .000,00$ \\
\hline
\end{tabular}


Tabel 4.Pengeluaran untuk 5 Tahun

\begin{tabular}{ccr}
\hline Tahun & & Pengeluaran \\
\hline Investasi & $\mathrm{Rp}$ & $25.000 .000,00$ \\
2019 & $\mathrm{Rp}$ & $92.066 .000,00$ \\
2020 & $\mathrm{Rp}$ & $94.929 .000,00$ \\
2021 & $\mathrm{Rp}$ & $113.839 .000,00$ \\
2022 & $\mathrm{Rp}$ & $101.107 .000,00$ \\
2023 & $\mathrm{Rp}$ & $104.446,000,00$ \\
\hline
\end{tabular}

\section{Tinjauan Pustaka}

Studi kelayakan dilakukan untuk mengetahui apakah investasi suatu usaha yang direncanakan atau sedang berlangsung layak atau tidak. Di dalamnya, dilakukan analisis pada aspek non finansial dan finansial. Dalam analisis kelayakan secara finansial, digunakan kriteria: NPV, IRR, BCR, dan PBP. Dalam analisis tersebut perlu ditentukan nilai MARR. Untuk mendapatkan gambaran yang lebih jelas tentang kelayakan suatu usaha, dapat dilakukan analisis sensitivitas. (Nabila, 2019)

\subsection{Aspek Non Finansial}

Aspek non finansial merupakan aspek kelayakan usaha yang penilaiannya tidak berdasarkan nominal uang secara langsung. Aspek non finansial yang ditinjau yaitu:

1. Aspek Pasar

Membahas permintaan, penawaran produk, harga, strategi pemasaran dan persaingan dengan usaha sejenis;

2. Aspek Teknis

Membahas pemilihan peralatan, pemilihan barang, proses usaha dan tata letak ruangan;

3. Aspek Manajemen dan Hukum

Membahas tentang perencanaan, struktrur organisasi, pelaksanaan, dan badan hukum usaha;

4. Aspek Sosial, Ekonomi dan Lingkungan

Membahas dampak yang diberikan usaha kepada sosial, ekonomi dan lingkungan.

Setiap komponen aspek aspek terebut dapat dianalisis untuk membantu pertimbangan dalam penentuan kelayakan sebuah usaha (Afiyah, 2015).

\subsection{NPV (Net Present Value)}

NPV adalah selisih antara nilai sekarang keseluruhan arus kas dengan biaya investasi yang dikeluarkan (Aneli, 2016). NPV dihitung dengan rumus sebagai berikut:

$$
N P V=\sum_{t=1}^{n} \frac{A t}{(1+i)^{t}}-I=\sum P W A-I
$$

di mana:

At = arus kas di akhir tahun ke-t

$\mathrm{n} \quad=$ periode investasi

$\mathrm{i} \quad=$ nilai suku bunga investasi

I $\quad=$ nilai investasi di awal

PW A = nilai sekarang arus kas

Kriteria kelayakan investasi berdasarkan NPV adalah:

NPV $<0$ : merugikan, tidak layak

$\mathrm{NPV}>0$ : menguntungkan, layak 


\subsection{PBP (Payment Back Period)}

PBP adalah jangka waktu yang diperlukan untuk membayar kembali investasi yang telah dikeluarkan. PBP merupakan tahun dimana NPV bernilai nol (Kusuma, 2014). Untuk lebih tepatnya, dapat digunakan rumus:

$$
P B P=\mathrm{n}_{1}+\frac{-N P V_{1}}{N P V_{2}-N P V_{1}} \times 1 \text { tahun }
$$

di mana:

$\mathrm{n}_{1} \quad=$ tahun terakhir dimana NPV bernilai negatif

$\mathrm{NPV}_{1}=$ nilai NPV negatif terkecil

$\mathrm{NPV}_{2}=$ nilai NPV positif terkecil

Kriteria kelayakan investasi berdasarkan PBP adalah:

PBP $>$ tahun investasi : tidak layak

$\mathrm{PBP}<$ tahun investasi : layak

\subsection{BCR (Benefit to Cost Ratio)}

BCR adalah perbandingan antara nilai sekarang manfaat dengan nilai sekarang biaya. BCR dapat dihitung dengan rumus:

$$
B C R=\frac{\sum P W \text { manfaat }}{\sum P W \text { biaya }}
$$

di mana:

PW manfaat = nilai sekarang manfaat

$\mathrm{PW}$ biaya = nilai sekarang biaya

Kriteria kelayakan investasi berdasarkan BCR adalah:

$\begin{array}{ll}\mathrm{BCR}<1 & : \text { tidak layak } \\ \mathrm{BCR}>1 & : \text { layak }\end{array}$

\subsection{IRR (Internal Rate of Return)}

IRR adalah tingkat bunga yang menyamakan nilai sekarang antara perkiraan arus kas masuk dengan arus kas keluar. Dengan kata lain, IRR merupakan tingkat bunga yang menyebabkan NPV menjadi 0 (Hidayati, 2017). IRR dapat ditentukan dengan rumus:

$$
I R R=i_{1}+\frac{N P V_{1}}{N P V_{1}-N P V_{2}} x\left(i_{2}-i_{1}\right)
$$

di mana:

$\mathrm{NPV}_{1}=\mathrm{NPV}$ bernilai negatif terkecil

$\mathrm{NPV}_{2}=\mathrm{NPV}$ bernilai positif terkecil

$\mathrm{i}_{1} \quad$ = suku bunga yang menghasilkan NPV

$\mathrm{i}_{2} \quad=$ suku bunga yang menghasilkan $\mathrm{NPV}_{2}$

Kriteria kelayakan investasi berdasarkan IRR adalah:

IRR $<\mathrm{i}$ : tidak layak

IRR > i : layak

dengan i adalah suku bunga yang digunakan oleh investasi. 


\section{MARR (Minimum Attractive Rate of Return)}

MARR adalah nilai minimal dari tingkat pemgembalian yang bisa diterima oleh investor. MARR digunakan sebagai patokan dasar dalam mengevaluasi berbagai alternatif investasi. Penentuan nilai MARR dalam analisis kelayakan suatu usaha tergantung dari: suku bunga pinjaman, suku bunga deposit, sumber modal dan tingkat risiko (Sulistiyo, 2014). Untuk menentukan nilai MARR dapat digunakan rumus:

$$
\begin{aligned}
& M A R R=\% \text { loan } \times \text { loan rate }+\% \text { equity } \times \text { MARRequity } \\
& \text { MARRequity }=\text { saferate }+ \text { risk rate }
\end{aligned}
$$

Di mana:

$$
\begin{array}{ll}
\text { \%loan } & =\text { persentase dana pinjaman } \\
\text { \%equity } & =\text { persentase modal sendiri } \\
\text { Loan rate } & =\text { suku bunga pinjaman } \\
\text { Safe rate } & =\text { suku punga deposit } \\
\text { Risk rate } & =\text { tingkat resiko }
\end{array}
$$

Nilai tingkat resiko ditentukan oleh pemilik usaha. Semakin tinggi keyakinan pemilik akan kesuksessan usaha, semakin kecil tingkat resiko.

\subsection{Analisis Sensitivitas}

Analisis sensitivitas dilakukan untuk meninjau kembali kelayakan terhadap perubahan faktor yang mempengarui kondisi finansialnya. Beberapa dari faktor tersebut contohnya yaitu perubahan pendapatan, pengeluaran atau investasi. Pada setiap kemungkinan perubahan, kriteria kelayakan (NPV, PBP, BCR, IRR) dapat dianalisis kembali. Apabila sedikit perubahan suatu faktor dapa mengubah kelayakan dengan cepat, maka dapat dikatakan usaha sangat sensitif terhadap faktor tersebut. Dengan mengetahui kesensitifitas suatu faktor, pemilik usaha dapat mengambil keputusan dengan lebih baik.

\section{Metode Penelitian}

Jenis penelitian ini merupakan studi kelayakan. Sumber data yang digunakan yaitu data primer dari nasarumber dan data sekunder dari studi literatur. Data yang diperoleh berupa data kuantitatif dan data kualitatif. Data kualitatif digunakan sebagai bahan analisis aspek non finansial. Data kuantitatif untuk digunakan analisis aspek finansial dan sensitivitas. Pengolahan dilakukan dengan menggunakan Spreadsheet untuk meminimalisasi kesalahan perhitungan. Apabila terdapat ketidaklengkapan data, dilakukan asumsi yang berdasar. Runtutan pengerjaan penelitian ini dilakukan berdasarkan diagram alir pada Gambar 2. 


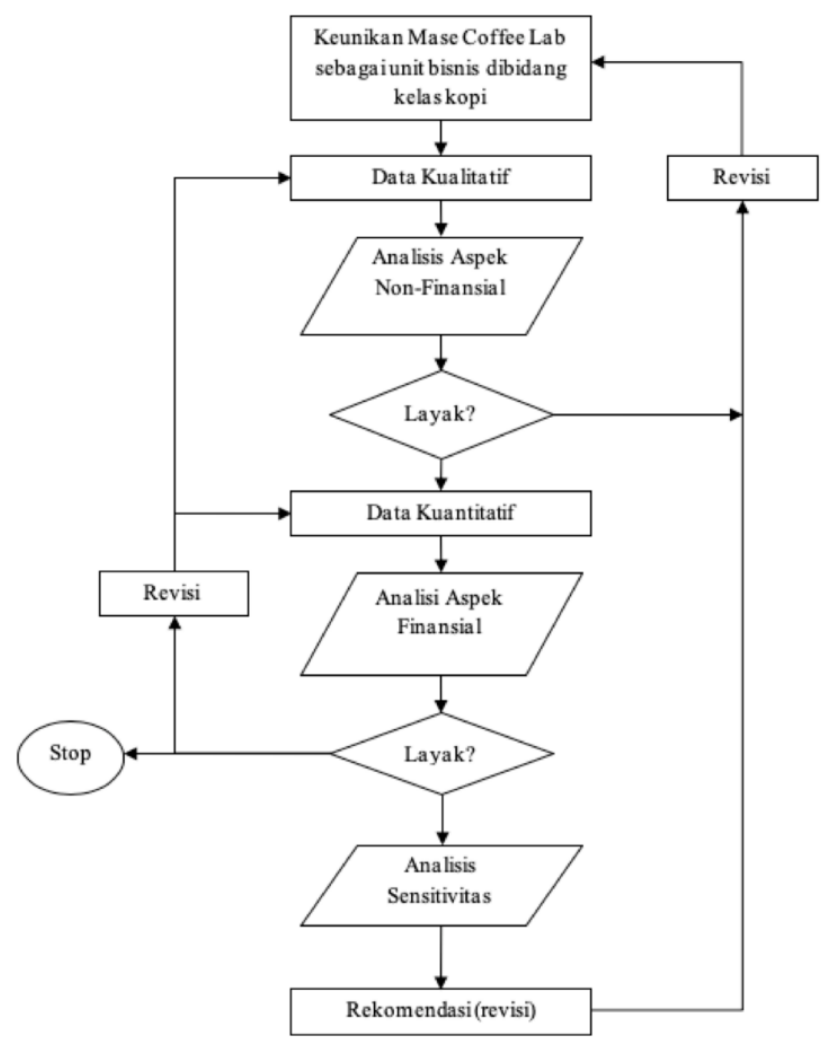

Gambar 1. Diagram Alir Prosedur Penelitian

\section{Hasil dan Pembahasan}

Hasil dan pembahasan terbagi menjadi tiga bagian: aspek non finansial, aspek finansial, dan sensitivitas. Hasil dari analisis aspek non finansial dan aspek finansial adalah berupa kelayakan usaha. Hasil dari analisis sensitivitas adalah faktor sensitif pada usaha.

\subsection{Aspek non Finansial}

Berdasarkan data kualitatif oleh narasumber didapatkan hasil untuk analisis aspek non finansial.

\section{Aspek Pasar}

Mase Coffee Lab dekat dengan jalan utama yaitu Jl. Ring Road Selatan National Rte 3, dan juga dekat dengan jalan-jalan besar lainnya yang menjadi akses utama ke beberapa kampus, kantor, dan tempat perbelanjaan, sehingga dari segi aksesibilitas Mase Coffee Lab sangat mudah untuk dijangkau seperti yang dapat dilihat pada Gambar 3. Pasar utama usaha adalah mahasiswa, dikarenakan memiliki ketertarikan dan waktu luang untuk belajar keahlian baru. Hal ini didukung dengan ditawarkannya harga produk yang relatif lebih rendah daripada usaha sejenis di sekitar. Dari segi pemasaran, dilakukan personal selling yaitu dengan mempromosikan secara langsung usaha di target pasar. Selain itu dilakukan public relation secara aktif dengan website dan akun sosial media Facebook dan Instagram. 


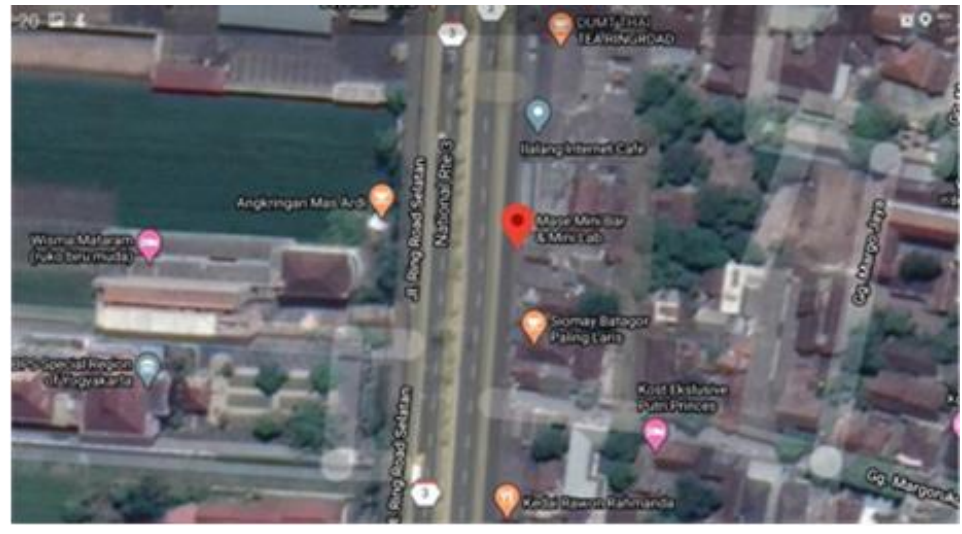

Gambar 2. Peta Lokasi Usaha

(sumber: www.google.com, diakses pada 19 Oktober 2020)

\section{Aspek Teknis}

Usaha beroperasi di dalam ruang seluas $4 \mathrm{~m} \times 15 \mathrm{~m}$. Tata letak seperti pada Gambar 4 telah dirancang supaya kegiatan dapat berlangsung dengan efisien. Di dalam ruangan tersebut akan dilakukan kegiatan pembelajaran dan praktek mengenai kopi. Dalam 1 bulan, terdapat 14 kali kegiatan dengan kapasitas maksimal 8 orang. Berdasarkan kegiatan tersebut, dipilih peratalan yang cukup awet (masa hidup 3 tahun). Selain itu, kegiatan dapat dilakukan dengan alat dan bahan yang standar, sehingga tidak membutukan biaya yang besar.

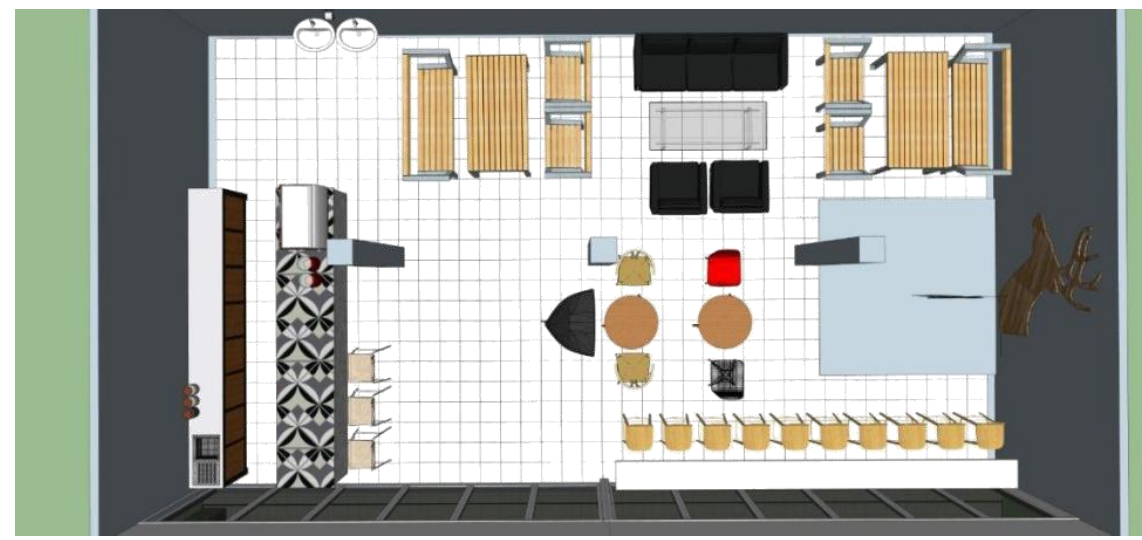

Gambar 4. Tata Letak Kelas Kopi

(sumber: data pemilik usaha)

\section{Aspek Manajemen dan Hukum}

Manajemen usaha dilakukan oleh pemilik Coffee Mase Lab. Dibawahnya, terdapat dua pegawai yang masing masing bertugas sebagai pengajar teori dan pengajar praktek. Dengan struktur organisasi tersebut kegaitan dengan total jam kerja 17 jam/minggu dapat diatur dengan mudah. Dari aspek hukum, usaha merupakan perusahaan perseorangan dan dapat dikategorikan sebagai Usaha Kecil Menengah (UKM). Sebelum melakukan usahanya, pemilik telah mendapatkan izin usaha serta izin dari pihak yang menyewakan bangunan. 


\section{Aspek Sosial, Ekonomi dan Lingkungan}

Usaha didirikan dengan dasar adanya kebutuhan akan pengetahuan dan keahlian berkaitan dengan kopi. Dilihat dari aspek sosial, hal tersebut tidak bertentangan, melainkan menambah nilai yang telah dimiliki masyarakat sekitar. Secara aspek ekonomi, adanya usaha memberikan lapangan pekerjaan baru dan dapat meningkatkan ekonomi nasional dengan membayar pajak yang telah ditetapkan. Secara aspek lingkungan, meskipun limbah yang dihasilkan sedikit, limbah tersebut telah dikelola dengan baik berdasarkan undang-undang dan aturan yang berlaku.

Untuk seluruh aspek non finansial yang ditinjau, didapatkan hasil yang baik. Usaha memiliki pasar yang baik, didukung dengan adanya harga bersaing yang ditawarkan dan promosi yang dilakukan. Dalam kegiatan usahanya, tata letak ruang, alat dan bahan telah dipertimbangkan dengan baik oleh pemilik usaha. Hal tersebut akan memudahkan proses manajemen oleh pemilik dan pegawai. Selain itu dari segi hukum, sosial, ekonomi dan lingkungan, usaha telah mengikuti aturan yang berlaku, terlebih memberikan nilai tambah pada masyarakat sekitar maupun secara luas. Dari aspek yang ditinjau, tidak ditemukan masalah yang berkemungkinan mengganggu keberlangsungan usaha. Maka dapat disimpulkan bahwa usaha layak secara non finansial.

\subsection{Aspek fiansial}

Arus kas setiap tahun pada Tabel 5 didapatkan dengan cara mengurangkan Tabel 4 dari Tabel 2. Sebelum melakukan analisis secara finansial, nilai MARR harus ditetapkan terlebih dahulu. Fungsi dari nilai MARR adalah untuk menghitung nilai sekarang (Present Worth, PW). Nilai tersebut merupakan pengganti nilai $i$ pada perhitungan NPV, PBP, BCR, dan IRR.

Penentuan nilai MARR dilakukan sesuai dengan rumus (5) dan (6). Nilai safe rate ditentukan berdasarkan nilai rata-rata suku bunga deposit beberapa bank di Indonesia yang tertera pada Tabel 6. Kemudian tingkat resiko ditetapkan senilai dengan safe rate. Karena sumber dana usaha ini sepenuhnya menggunakan dana pribadi, maka \%loan adalah $0 \%$ dan \%equity adalah $100 \%$. Sehingga didapatkan:

$$
\begin{aligned}
\text { MARR } & =100 \% \times(5,025 \%+5,025 \%) \\
& =10,05 \%
\end{aligned}
$$

Tabel 5. Arus Kas Setelah Pajak

\begin{tabular}{crr}
\hline Tahun ke- & \multicolumn{1}{c}{ Arus Kas } \\
\hline 0 & $-\mathrm{Rp}$ & $25.000 .000,00$ \\
1 & $\mathrm{Rp}$ & $11.912 .000,00$ \\
2 & $\mathrm{Rp}$ & $17.367 .000,00$ \\
3 & $\mathrm{Rp}$ & $7.441 .000,00$ \\
4 & $\mathrm{Rp}$ & $29.875 .000,00$ \\
5 & $\mathrm{Rp}$ & $37.016,000,00$ \\
\hline
\end{tabular}

\section{Hasil NPV}

Berdasarkan nilai MARR yang telah didapatkan, PW arus kas dapat dihitung. Kemudian berdasarkan rumus (1) didapatkan nilai NPV untuk setiap tahunnya seperti pada Tabel 7. Dari tabel tersebut, didapatkan nilai positif NPV pada akhir masa investasi sebesar yaitu Rp 49.046.768,59. 
Tabel 6. Suku Bunga Deposit Beberapa Bank

\begin{tabular}{lcc}
\hline & Nama Bank & Suku Bunga \\
\hline Bank Mandiri & $5,00 \%$ \\
Bank Danamon Indonesia & $5,30 \%$ \\
Bank Central Asia & $4,10 \%$ \\
Bank Rakyat Indonesia & $5,40 \%$ \\
Bank Cimb Niaga & $5,10 \%$ \\
Bank Maybank Indonesia & $4,90 \%$ \\
Bank Panin Indonesia & & $5,30 \%$ \\
Bank Negara Indonesia & Rata-rata & $5,10 \%$ \\
\hline
\end{tabular}

(sumber: kontan.co.id, 2020)

\begin{tabular}{crr} 
Tabel 7.Hasil Perhitungan NPV & \\
\hline Tahun ke- & \multicolumn{1}{c}{ NPV } \\
\hline 0 & $-\mathrm{Rp}$ & $25.000 .000,00$ \\
1 & $-\mathrm{Rp}$ & $14.175 .829,17$ \\
2 & $\mathrm{Rp}$ & $164.024,20$ \\
3 & $\mathrm{Rp}$ & $5.746 .941,10$ \\
4 & $\mathrm{Rp}$ & $26.114 .910,16$ \\
5 & $\mathrm{Rp}$ & $49.046 .768,59$ \\
\hline
\end{tabular}

\section{Hasil PBP}

Nilai PBP dapat ditentukan berdasarkan rumus (2). Dari Tabel 7 diketahui nilai $\mathrm{NPV}_{1}$ sebesar -Rp 14.175.829,17 pada tahun ke-1 dan $\mathrm{NPV}_{2}$ sebesar Rp 164.024,20 pada tahun ke-2. Sehingga didapatkan PBP dalam tahun sebesar:

$$
P B P=1+\frac{14 \cdot 175 \cdot 829,17}{164 \cdot 024,20+14 \cdot 175 \cdot 829,17}=1,989
$$

Biaya investasi yang dikeluarkan seluruhnya akan terbayarkan kembali setelah 1,989 tahun atau 2 tahun masa investasi.

\section{Hasil BCR}

Nilai BCR dapat ditentukan berdasarkan rumus (3). Dalam studi kelayakan ini, manfaat dan biaya masing masing adalah pendapatan dan pengeluaran. PW dari masing masing manfaat dan biaya dihitung lalu dijumlahkan.

Tabel 8. Perhitungan PW Manfaat

\begin{tabular}{ccr}
\hline Tahun ke- & PW Manfaat \\
\hline 0 & $\mathrm{Rp}$ & - \\
1 & $\mathrm{Rp}$ & $94.482 .507,95$ \\
2 & $\mathrm{Rp}$ & $92.722 .299,41$ \\
3 & $\mathrm{Rp}$ & $90.995 .318,12$ \\
4 & $\mathrm{Rp}$ & $89.299 .994,05$ \\
5 & $\mathrm{Rp}$ & $87.637 .415,11$ \\
\hline Total & $\mathrm{Rp}$ & $455.137 .534,64$ \\
\hline
\end{tabular}


Tabel 9 Perhitungan PW Biaya

\begin{tabular}{ccr}
\hline Tahun ke- & \multicolumn{2}{c}{ PW biaya } \\
\hline 0 & $\mathrm{Rp}$ & $25.000 .000,00$ \\
1 & $\mathrm{Rp}$ & $83.658 .337,12$ \\
2 & $\mathrm{Rp}$ & $78.382 .446,04$ \\
3 & $\mathrm{Rp}$ & $85.412 .401,21$ \\
4 & $\mathrm{Rp}$ & $68.932 .025,00$ \\
5 & $\mathrm{Rp}$ & $64.705 .556,67$ \\
\hline Total & $\mathrm{Rp}$ & $406.090 .766,05$ \\
\hline
\end{tabular}

Maka didapatkan nilai BCR yaitu:

$$
\begin{aligned}
B C R & =\frac{\operatorname{Rp} 455 \cdot 137 \cdot 534,64}{\operatorname{Rp} 406 \cdot 090 \cdot 766,05} \\
& =1,121
\end{aligned}
$$

Nilai tersebut menunjukkan bahwa perbandingan antara manfaat dan biaya untuk investasi adalah sebesar 1,121 .

\section{Hasil IRR}

Perhitungan IRR dilakukan menggunakan Spreadsheet. Dengan fitur "Goal Seek" supaya mendapatkan NPV bernilai 0 dengan cara merubah nilai MARR. Didapatkan nilai IRR yaitu sebesar $57,84 \%$.

Dari segi aspek finansial, usaha kelas kopi merupakan usaha yang layak. Hal tersebut dapat disimpulkan karena semua kriteria kelayakan telah terpenuhi. Rangkuman analisis aspek finansial dapat dilihat pada Tabel 10.

\begin{tabular}{cc}
\multicolumn{2}{c}{ Tabel 10. Hasil Analisis Aspek Finansial } \\
\hline Kriteria & Kelayakan \\
\hline NPV & Rp 49.046.768,59>0 \\
Layak \\
PBP & 2 tahun $<5$ tahun \\
& Layak \\
BCR & $1,121>1$ \\
& Layak \\
IRR & $57,84 \%>10,05 \%$ \\
& Layak \\
\hline
\end{tabular}

Nilai NPV tersebut berarti bahwa nilai yang didapatkan pada akhir masa investasi adalah setara dengan Rp 49.046.768,59 pada masa sekarang. Dengan nilai PBP sebesar 2 tahun, maka usaha akan mendapatkan keuntungan bersih mulai dari awal tahun ke-3 atau tahun 2021. Nilai BCR sebesar 1.121 menunjukkan bahwa setiap biaya sebesar Rp 1,00 yang dikeluarkan, didapatkan manfaat sebesar Rp 1,12. Terakhir, investasi ini dapat memberikan keuntungan yang lebih banyak dibandingkan dengan IRR sebesar 57,84\%. Selain hanya layak, usaha dengan MARR sebesar $10,05 \%$ ini memberikan keuntungan yang cukup baik.

\subsection{Sensitivitas}

Pada studi kelayakan ini, terdapat dua faktor yang dianalisis sensitivitasnya. Faktor tersebut adalah jumlah peserta kelas kopi dan biaya operasional. Jumlah peserta kelas adalah sumber utama pendapatan, maka perlu diketahui dampak perubahannya terhadap kelayakan usaha kelas kopi. Lalu kenaikan biaya operasional perlu dipertimbangkan mengingat adanya kemungkinan terjadi 
inflasi. Berdasarkan pertimbangan tersebut, ditetapkan beberapa skenario sensitivitas seperti pada Tabel 11. Sebagai catatan, nilai yang dijadikan acuan perubahan adalah nilai awal yaitu pada tahun 2019 (huruf tebal).

Tabel 11. Skenario Analisis Sensitivitas

\begin{tabular}{lcc}
\hline Skenario & $\begin{array}{c}\text { Perubahan } \\
\text { Jumlah } \\
\text { Peserta(\%) }\end{array}$ & $\begin{array}{c}\text { Perubahan Biaya } \\
\text { Operasional (\%) }\end{array}$ \\
\hline Pesimis & $-8,-4,0$ & 20 \\
Wajar & $4, \mathbf{8}$ & 10,15 \\
Optimis & 12 & $\mathbf{0 , 5}$ \\
\hline
\end{tabular}

\section{Sensitivitas Jumlah Peserta}

Untuk setiap skenario yang telah ditetapkan, dilakukan analisis aspek finansial seperti pembahasan sebelumnya. Hal yang dianalis adalah nilai NPV, dengan asumsi nilai selain jumlah peserta tidak berubah. Hasil analisis sensitivitas jumlah peserta dapat dilihat pada Tabel 12 dan Gambar 5.

\begin{tabular}{crr}
\multicolumn{3}{c}{ Tabel 12 Analisis Sensitivitas Jumlah Peserta } \\
\hline Perubahan (\%) & \multicolumn{2}{c}{ NPV } \\
\hline-8 & $-\mathrm{Rp}$ & $41.024 .279,35$ \\
-4 & $-\mathrm{Rp}$ & $21.020 .858,58$ \\
0 & $\mathrm{Rp}$ & $594.165,81$ \\
4 & $\mathrm{Rp}$ & $23.916 .807,45$ \\
8 & $\mathrm{Rp}$ & $49.046 .768,59$ \\
12 & $\mathrm{Rp}$ & $76.089 .748,50$ \\
\hline
\end{tabular}

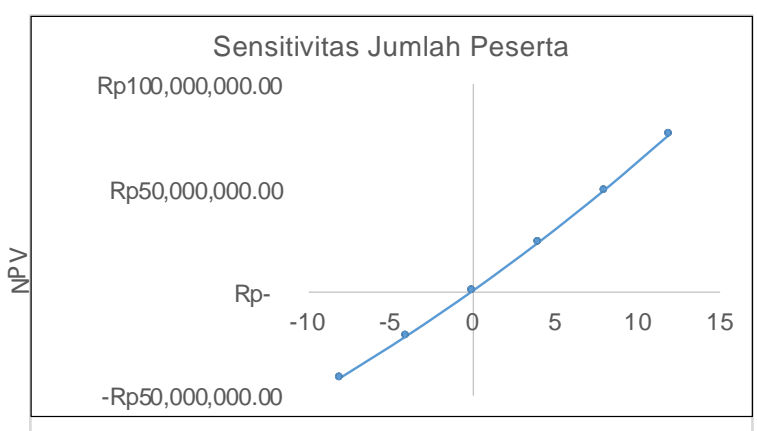

Gambar 5. Grafik Sensitivitas dengan variabel Jumlah Peserta

\section{Sensitivitas Biaya Operasional}

Dilakukan hal yang sama seperti analisis sensitivitas jumlah peserta. Biaya operasional merupakan sebagian dari total pengeluaran. Dalam hal ini biaya perawatan, sewa bangunan, serta gaji pegawai tidak berubah dari rencana yang telah ditetapkan. Selain itu, faktor selain pengeluaran juga dianggap tetap. Hasil analisis sensitivitas biaya operasional dapat dilihat pada Tabel 13 dan Gambar 6.

Tabel 13. Analisis Sensitivitas Biaya Operasional

\begin{tabular}{crr}
\hline Perubahan (\%) & \multicolumn{2}{c}{ NPV } \\
\hline 0 & $\mathrm{Rp}$ & $49.046 .768,59$ \\
5 & $\mathrm{Rp}$ & $38.014 .669,57$ \\
10 & $\mathrm{Rp}$ & $25.866 .666,61$ \\
15 & $\mathrm{Rp}$ & $12.521 .430,69$ \\
20 & $-\mathrm{Rp}$ & $2.105 .374,06$ \\
\hline
\end{tabular}




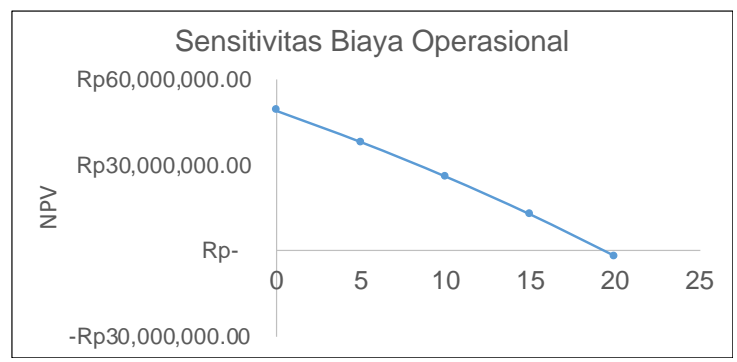

Gambar 6. Grafik Sensitivitas dengan variabel Biaya Operasional

Pada Tabel 12 dan Tabel 13 terdapat beberapa nilai dengan nilai negative. Hal tersebut menandakan bahwa nilai tersebut tidak memenuhi kriteria kelayakan. Hampir seluruh skenario pesimis menebabkan ketidaklayakan usaha. Skenario $0 \%$ untuk jumlah peserta tidak menyebabkan perubahan kelayakan akan tetapi nilai tersebut perlu diperhatikan.

Untuk jumlah peserta, penurunan sebanyak 4\% dan 8\% dari 201 menyebabkan usaha menjadi tidak layak. Ketika tidak terjadi perubahan jumlah peserta, didaptkan nilai NPV yang sangat kecil. Dapat diperkirakan akan terjadi kerugian apabila terjadi penurunan peserta selama masa investasi, meskipun kecil. Perubahan 0\% tersebut dapat disebut dengan perubahan kritikal. Lalu nilai asumsi awal yang digunakan adalah $8 \%$. Ketika terdapat sedikit perbedaan dari asumsi awal (4\% dan $12 \%)$, usaha masih dikatakan layak.

Untuk biaya operasional, usaha menjadi tidak layak ketika terjadi kenaikan sebesar $20 \%$ dari biaya diawal tahun. Dengan perhitunga lebih lanjut didapatkan titik kritikal yaitu kenaikan sebesar $19,3 \%$. Usaha dapat dikatakan layak apabila terjadi kenaikan biaya yang lebih kecil dari nilai tersebut.

\begin{tabular}{lcc}
\multicolumn{2}{c}{ Tabel 14. Perbandingan Analisis Sensitivitas } \\
\hline Perubahan & $\begin{array}{c}\text { Jumlah } \\
\text { Peserta }\end{array}$ & $\begin{array}{c}\text { Biaya } \\
\text { Operasional }\end{array}$ \\
\hline \%Awal & 8 & 0 \\
\%Kritikal & 0 & 19.3 \\
\hline \%Perbedaan & 8 & 19.3 \\
\hline
\end{tabular}

Jika dibandingkan seperti pada Tabel 14, terlihat bahwa jumlah peserta memiliki sensitivitas yang lebih tinggi. Hal ini dapat disimpulkan karena jumlah peserta memiliki perbedaan perubahan terkecil di antara kedua faktor yang dianalisis. Dapat diartikan bahwa diperlukan perubahan sebanyak $8 \%$ jumlah peserta dari rencana awal sehingga usaha menjadi tidak layak. Sedangkan untuk biaya operasional, diperlukan perubahan sebanyak $19,3 \%$.

\section{Kesimpulan}

Pada studi ini telah dilakukan analisis kelayakan untuk kelas kopi pada Coffee Mase Lab di Bantul, Yogyakarta. Telah dilakukan analisis pada aspek non finansial dan aspek finansial. Hasil menunjukkan bahwa investasi yang dilakukan pada usaha tersebut layak terlihat bahwa jumlah peserta memiliki sensitivitas yang lebih tinggi. Hal ini dapat disimpulkan karena jumlah peserta memiliki perbedaan perubahan terkecil di antara kedua faktor baik jumlah peserta dan operasional yang dianalisis. Dapat diartikan bahwa diperlukan perubahan pengurangan peserta sebanyak $8 \%$ dari rencana awal sehingga usaha menjadi tidak layak. Sedangkan untuk biaya operasional, diperlukan perubahan penambahan sebanyak $19,3 \%$ untuk menjadikan usaha menjadi tidak layak. Sehingga untuk mengantisipasi hal tersebut, dapat dilakukan upaya meningkatkan jumlah peserta dengan cara pemberian sertifikasi, atau dengan meningkatkan kuota kelas. 


\section{Ucapan Terima Kasih}

Puji dan syukur penulis panjatkan kepada Tuhan Yang Maha Esa sehingga artikel ini dapat diselesaikan dengan baik. Selesainya artikel ini tidak terlepas dari dukungan dan bantuan dari beberapa pihak. Karena itu, penulis menyampaikan ucapan terima kasih kepada Fathur Rahman Afkha Sirait, atas informasi dan data yang diberikan mengenai usaha kelas kopi pada Mase Coffee Lab.

\section{Daftar Pustaka}

International Coffee Organization, 2017. International Coffee Organization. [Online] Available at: www.ico.org/ [Diakses pada 1 Maret 2020].

Kementrian Pertanian, 2018. Outlook Kopi 2018. Jakarta: Portal Epublikasi Pertanian.

Nurikhsan, Farhan. dkk (2019). "Fenomena Cofee Shop di Kalangan Konsumen Remaja". Jurnal Widya Komunika, 9(2), pp. 137-144

Bernas.id, 2018. Bisnis Warung Kopi di Yogyakarta Cukup Menjanjikan, Yogyakarta: Bernas.id.

Sanaky, Hujair AH., dkk (2018). "Peningkatan dan Pengembangan Produk Olahan Kopi di Desa Brunosari". Asian Journal of Innovation and Entrepreneurship, 3(3), pp. 272-284

Majalah Hortus, 2019. Majalah Hortus Archipelago. [Online] Available at: https://news.majalahhortus.com/konsumsi-kopi-nasional-tumbuh-8-persen- per-tahun/ [Diakses pada 29 April 2020].

Nuryanti, Yanti,dkk (2017). "Analisis Biaya, Pendapatan dan R/C Agroindustri Keripik Pisang”. Jurnal Ilmiah Mahasiswa AGROINFO GALUH, 4(3), pp. 396-401.

Putra, Reysa, T., E. A., (2018). “Analisis Kelayakan Pembangunan Unit Bisnis Sangrai Kopi Pada Brewisely Coffeemate Ditinjau Dari Aspek Pasar, Aspek Teknis, Aspek Finansial”. eProceeding of Management, 5(1), pp. 134-140.

Nabila Ananda Putri, Z. S. D. S. L. T., (2019). "Analisis Kelayakan Bisnis Kedai Kopi (Studi Kasus Pada Agrowisata N8 Malabar, Pangalengan, Kabupaten Bandung)”. Journal of Food System and Agribusiness, 3(2), pp. 89-100.

Widra Kristian, F. I., (2017). "Studi Kelayakan Bisnis dalam Rangka Pendirian XX Café”. Jurnal Akuntansi Maranatha, 11(2), pp. 379-400.

Ida Bagus Gede Ardyana Pemaron S, I. K. S. I. W. G. S. Y., (2015). "Rencana Bisnis Pengembangan Usaha Pengolahan Kopi Arabika (Coffea Arabica) Di Subak Abian Ulian Murni, Kintamani - Bangli”. Jurnal Rekayasa dan Manajemen Agroindustri, 3(3), pp. 61-71.

Nauval Furqon Amaly, B. P. M. I., 2015. Analisis Kelayakan Pembukaan Cabang Coffee Shop Kedai Sabi Di Tamansari, Kota Bandung Ditinjau Dari Aspek Pasar, Aspek Teknis, Dan Aspek Finansial. e-proceeding of Engineering, 2(2), pp. 40-48.

Afiyah, Abidatul, dkk (2015). "Analisis Studi Kelayakan Usaha Pendirian Home Industry". Jurnal Administrasi Bisnis, 23(1), pp. 1-11. 
Aneli, Dwi.dkk (2016). "Penilaian Kelayakan Usaha Konveksi UMKM Berkat Selaku Mitra Binaan UPT Tekstil Divisi Produk Pakaian Jadi Dinas Perindustrian dan Perdagangan Provinsi Sumatera Selatan berdasarkan Aspek Keuangan untuk Mengembangkan Strategi Bisnis” Jurnal Ilmiah ORasi Bisnis, 16, pp. 99-113.

Purnatiyo, Dwinanto (2016). “Analisis Kelayakan Investasi Alat DNA Real Time Thermal Cycler (RT-PCR) untuk Pengujian Gelatin” Jurnal PAsti Vol. 8 No. 2, pp. 212-226.

Kusuma, Parama T.W.W. (2014). "Analisa Kelayakan Finansial PEngembangan Usaha Produksi Komoditas Lokal : Mie Berbasis Jagung” AGRITECH Vol. 34 No. 2, pp. 194-202.

Hidayati, Nurul, dkk. (2017). "Analisa Kelayakan Finansial Kelas Alam Terbuka Kebumian dan Lingkungan Berkonsep Rekreasi dan Inspirasi untuk Anak di Surabaya" Prosiding Seminar Nasional Multi Disiplin ilmu dan Call for Paper UNISBANK, pp. 650-656. 